\title{
Examining the Digital Learning Material Preparation Competencies of Pre- Service Mathematics Teachers
}

\author{
Mertkan Şimşek * \\ Department of Mathematics and Science Education, Agri Ibrahim Cecen University, \\ Agri, Turkey \\ ORCID: 0000-0002-5613-0299
}

\author{
Nurullah Yazıcı \\ Department of Mathematics and Science Education, Karamanoglu Mehmetbey University, \\ Karaman, Turkey
}

ORCID: 0000-0002-5594-8347

\begin{tabular}{l}
\hline Article history \\
\hline Received: \\
01.01 .2021
\end{tabular}

Received in revised form: 07.02.2021

Accepted:

10.02.2021

Key words:

Mathematics teaching;

Digital materials;

GeoGebra,

Evaluation by rubric
The aim of this research is to examine digital learning materials designed by pre-service mathematics teachers with GeoGebra software through rubrics. This research was conducted using the integrative mixed method design, which allows the use of qualitative and quantitative methods together or sequentially. The study group of the research consists of 46 pre-service teachers studying in elementary mathematics education programme and attending the Computer-Assisted Mathematics Instruction course in a university. The pre-service teachers designed the materials in groups of two (23 participant per group). Semi-structured interviews were conducted with six groups determined according to the purposeful sampling selection. The data of this research were obtained using digital learning materials and semi-structured interview form used to interview pre-service teachers. Pre-service teachers were asked to prepare a material that can be used in teaching simple fractions addition with GeoGebra software. In line with the purpose of the study, the Digital Learning Material Evaluation Rubric has been developed by the researchers. When the Digital Learning Material Evaluation Rubric scores of the pre-service teachers who participated in the study were examined, it was found that there were deficiencies in the digital learning material design skills of the pre-service teachers. Pre-service teachers were less successful in terms of teaching appropriateness than structural appropriateness and programming appropriateness aspects of the digital learning materials produced.

\section{Introduction}

It is aimed to increase the quality of learning-teaching environments with the concept of education technology that emerged by blending education and technology concepts (İşman, 2015). Because with the use of technology in education, students will be able to analyze the problem situations they encounter better, develop various hypotheses with their own methods

\footnotetext{
*Correspondency: mertkans@gmail.com
} 
and decide on appropriate solutions (Ministry of National Education [MoNE], 2018). However, while students focus on learning, their willingness and self-confidence to learn will also increase. Thus, a positive contribution will be made to the development of personal skills (Heafner, 2004; Lloyd, 2013).

Teachers are an important part of the integration of education and technology concepts (Arslan \& Şendurur, 2017; Inan \& Lowther, 2010; İşman, 2015; Soydan, 2018). Therefore, teachers should have sufficient knowledge of educational technology, especially regarding digital learning material preparation. Thus, it will be easier to create a constructivist teaching environment (Takıcak, 2016). In addition, teachers should lead students in accessing digital learning materials (Çakır \& Oktay, 2013). In the teaching process, teacher-student communication is generally maintained through teaching materials. At this point, the importance of digital learning materials is an undeniable fact (Soydan, 2018). The results of the research indicate that the technology and materials used by teachers in the in-class teaching process make teaching more enjoyable (Demirel, 2011; Özkurt, 2017; Sipahioğlu, 2019).

As much as the use of technology and materials in education is necessary, it is also necessary to know the design and application processes of the materials to be used (Özkurt, 2017). Considering that the use of instructional technologies and digital learning materials is the responsibility of teachers, it is not enough to improve technology infrastructure alone (Koehler \& Mishra, 2005). Therefore, it is a professional requirement for teachers to have instructional technology and technology-based material design skills (Ornstein \& Lasley, 2000; Mishra \& Koehler, 2006; Karamustafaoğlu, 2012; Tezci \& Perkmen, 2013; Phillips, 2013; Soydan, 2018; Stevenson et al., 2019). In summary, it is important for teachers to integrate teaching materials with technology from the perspective of an instructional designer and to benefit from these materials in the teaching process to reach goals yielding effective results in a permanent fashion (Koşar \& Çiğdem, 2003; Kolburan Geçer, 2010; Tezci \& Perkmen, 2013). However, teachers have responsibilities in responding to the differing expectations of the Z-generation (digital generation), that is, in shaping the teaching environments to allow the use of innovative teaching technologies (Somyürek, 2014). In the relevant research, it has been determined that teachers who have the skills of using and designing digital teaching materials required by the Z-generation education and catering to student perspectives increase the interest and desire of the students. In addition, it has been determined that these teachers are more successful in terms of permanent and meaningful learning or regarding achieving teaching goals (Akçay, Tüysüz, Feyzioğlu, \& Oğuz, 2008; Baki, Yalçınkaya, Özpınar, \& Uzun, 2009; Uyangör, \& Ece, 2010; Korkmaz, 2011; Lloyd, 2013; Genç \& Öksüz, 2016; Phillips, 2013; Turel, \& Sanal, 2018). Because it is known that teaching materials can respond to developmental needs by taking into account the individual differences of students and such materials can indeed make teaching more enjoyable and effective (Demirel, 2011; Demirel \& Yağc1, 2017; Şahin \& Yıldırım, 2001).

It is obvious that using educational technologies in mathematics teaching will develop a positive perspective towards mathematics lesson in today's world where the use of technology in education is widespread (Onal \& Göloğlu Demir, 2013). From the students' perspective, mathematics is a lesson that is not related to daily life and is known as boring and difficult. Therefore, teaching activities can be shaped by using computer-assisted software and effective digital learning materials (Bayturan, 2011). In this context, both the strengthening of the hardware infrastructure of the schools and the development of mathematics and geometry software increase the importance of computer-assisted mathematics teaching day by day. 
Software used in mathematics teaching and learning can be considered under two headings as computer algebra systems (CAS) and dynamic geometry software (DGS): While CAS software (Derive, Maple, Mathematica and alike) focuses on processing mathematical expressions in symbolic form; DGY is software (Cabri, Cabri Geometry and Geometer's Sketchpad, and others) that combines geometric structures such as point, line, circle and dynamic figures such as function graphics (Preiner, 2008). GeoGebra software includes the basic features of CAS and DGS. In addition, GeoGebra is a free software that can be used in mathematics lessons at all levels from primary school to university level, which has been approved by the MoNE, and which has many language support systems (Hohenwarter \& Jones, 2007; Buteau, Jarvis, \& Lavicza, 2014). In the research, although teachers have sufficient computer skills, it has been stated that they are deficient in integrating the curriculum with technology (Lloyd, 2013; Karaca, 2015; Hew \& Brush, 2007; Riasati, Allahyar, \& Tan, 2012; Wilson, Ritzhaupt, \& Cheng, 2020). However, in many studies, it was determined that pre-service teachers have positive ideas about using technology in classroom teaching activities (Aktepe, 2011; Teo, 2009).

The adequacy of the materials designed by teachers, who are at the center of technology integration, should also be evaluated according to certain criteria. Many digital learning materials designed by teachers are not functional or useful because software evaluation criteria are ignored (Karal, Fiş Erümit, \& Çimer, 2010). For this reason, it is important that designed digital teaching materials pass certain evaluation criteria. Şahin and Yildırım (2001) stated that four basic elements should be considered in the evaluation of digital learning materials. These elements are expressed as follows: teaching appropriateness, teaching programme appropriateness, structural appropriateness and programming appropriateness. In this context, rubrics prepared according to the evaluation criteria specified by Şahin and Y1ldirım (2001) can be used in the evaluation of digital learning materials. Rubrics consist of certain criteria and these criteria are used to measure a performance, a quality or a behavior gradually (Moskal Barbara, 2000; Yazıc1, 2013).

Concretizing is important in transforming mathematical knowledge into permanent and meaningful learning (Kelly, 2006; Van de Walle, 2013). In the mathematics learning-teaching process, abstract concepts can be presented by concretizing them with visual representations through GeoGebra software. According to Kutluca and Zengin (2011), the relationships between mathematical concepts will be better understood by students through enhancing the visuality (i.e., making them concrete) with GeoGebra software. Some researchers stated that students had difficulties in fractions in the mathematics program (Haser \& Ubuz, 2003; Orhun, 2007; Kılıç \& Özdaş, 2010; Olkun \& Toluk-Uçar, 2014; Uz, 2018). In some of these studies like Orhun's (2007) it is stated that students have difficulties in expressing fractions visually and working with fractions. Uz (2018) also stated that students perceive the concept of fraction as an abstract one and therefore have difficulties in learning. As a result of the conceptual understanding of fractions, it is certain that other advanced topics will be learned and problem solving skills will be developed (Sharp \& Adams, 2002). For this, while working on the fraction concept, it should be concretized by using models and figures (Biber, Tuna, \& Aktaş, 2013). In addition, using visual and digital learning materials in fraction teaching will enable students to actively participate in the process (Tutak, 2009). With this feature, rubrics can be prepared in many different ways and levels. In this study, it was aimed to examine digital learning materials designed by pre-service mathematics teachers using GeoGebra software through rubrics. In the research, the subject, 6th grade "Does addition and subtraction with fractions." (MoNE, 2018) has been selected to create digital learning materials. For this purpose, answers to the following questions were sought: 
(1) Do the pre-service teachers' digital learning material design scores differ significantly in terms of rubric sub-dimensions of teaching appropriateness, teaching programme appropriateness, structural appropriateness and programming appropriateness?

(2) How are pre-service teachers' digital learning material design skills when analyzed in terms of rubric sub-dimensions of teaching appropriateness, teaching programme appropriateness, structural appropriateness and programming appropriateness?

\section{Method}

\section{Research Model}

This research was conducted using the integrative mixed method design, which allows the use of qualitative and quantitative methods together or sequentially in order to provide a more detailed and comprehensive understanding of the situation under consideration by using the advantages of qualitative and quantitative designs (Plano Clark \& Creswell, 2011; Mills \& Gay, 2016). In the integrative mixed method research, the purpose of detailing, exemplifying and explaining the results obtained with a determined design with the results of the other design is at the forefront (Greene, 2007; Bryman, 2007). In this study, firstly, the functionality and usefulness level of the materials designed by pre-service teachers were determined with the digital learning material evaluation rubric. Afterwards, in-depth observations and interviews were made, and the approaches of the pre-service teachers were evaluated.

According to Creswell and Creswell (2017), in mixed method research, two designs that are mixed method can be integrated in four different ways. One of these is to integrate the data for disclosure. That is, the integration of quantitative data to explain qualitative data results (or vice versa viz. using qualitative data for quantitative data results). In this study, it was intended to elaborate on and explain the results of quantitative data obtained through the digital learning material evaluation rubric by interviewing.

\section{Sample of the Study}

The study group of the research consists of 46 pre-service teachers studying in elementary mathematics education programme attending the "Computer-Assisted Mathematics Instruction" course in a university in Turkey. The pre-service teachers designed the materials in groups of two (23 participant per group). Semi-structured interviews were conducted with six groups determined according to the purposeful sampling selection (Büyüköztürk, 2016) in the context of conducting in-depth research and selecting rich situations among pre-service teachers.

\section{Instrument}

The data of this study were obtained using digital learning materials and semistructured interview form referred to while interviewing pre-service teachers. Pre-service teachers were asked to prepare a material that can be used in teaching simple fractions addition with GeoGebra software. Pre-service teachers attended the "Computer- Assisted Mathematics Instruction" lesson in which the use of GeoGebra was taught for 10 weeks before the material design. During this 10-week period, the students used the Geogebra software in the following order:

- Introducing the GeoGebra interface (algebra window, graphics window, tools etc.)

- Introduction to digital learning materials using mathematical objects (line, line segment, circle, polygon, angle, and so on.). 
- Use of necessary tools to design dynamic materials.

- Examining the situations that need to be considered in the digital learning material preparation stages.

The necessary feedback was provided by the researchers about the situations where the preservice teachers experienced deficiencies in terms of program usability and technical competence. In addition, the pre-service teachers have successfully completed the "Material Design in Mathematics Teaching, Information Technologies" and "Instructional Technologies" courses in the previous terms. Therefore, it is thought that they have preliminary information about the situations that need attention in material design.

A semi-structured interview form was prepared in order to support the quantitative data and to better define the material processes of the pre-service teachers. With the interview form, the difficulties pre-service mathematics teachers encountered in the process and the situations they paid attention to in preparing the material were tried to be determined. The interview form consists of the following questions:

- What are the difficulties when preparing digital learning material? Explain in line with the technical negativities, difficulties that may be experienced due to the nature of the concept, and the difficulties encountered at the level of content knowledge of the concept.

- What are the most important objects in the digital learning material you prepared that make the material effective? Explain in terms of visuality, color, form, content, dynamism, interaction, student-centeredness, usefulness.

- What are your views on using the GeoGebra software for digital learning material preparation?

\section{Data Analysis}

In line with the purpose of the study, the digital learning material evaluation scale prepared by Şahin and Yildırım (2001) was used for the conformity of the evaluation of digital learning materials to the conceptual framework. Based on this, the Digital Learning Material Evaluation Rubric [DLMER] has been developed by the researchers. DLMER consists of four dimensions. These dimensions are "teaching appropriateness, teaching programme appropriateness, structural appropriateness" and "programming appropriateness" (Şahin \& Yıldırım, 2001). Each dimension is divided into four sub-dimensions within itself. Teaching appropriateness dimension consists of "activating learning, increasing motivation, adequacy of content" and "presenting summary / sufficient information" sub-dimensions. The dimension of teaching programme appropriateness consists of sub-dimensions of "being suitable for different learning styles, contributing positively to student success, being flexible in terms of use" and "being able to use the material alone". The structural appropriateness dimension consists of "color compatibility, use of the screen area, simplicity of the screen design" and "screen readability" sub-dimensions. The programming appropriateness dimension consists of the sub-dimensions of "working without errors, providing usage instructions, appropriate interaction level" and "being suitable for use with all equipment". In addition, performance indicators and performance levels were determined according to each of the four sub-dimensions. The performance levels of DLMER are determined as "insufficient, partially sufficient" and "sufficient" from the lowest level to the highest level. In this case, scoring values such as "one" for unsatisfactory, "two" for partially sufficient and "three" for sufficient were used. The average scores of each group on the basis of sub- 
dimensions were calculated with numerical data. After the data were digitized, the subdimension scores of each group were created by calculating the averages of the item scores. Jamovi (The jamovi project, 2020) software was used in the analysis of the quantitative data collected through DLMER. In order to test the significance of the difference between subdimensions, the Friedman Test, which is the nonparametric equivalent of the one-factor ANOVA test, was used. Since the data did not show normal distribution, the test, which is the non-parametric equivalent of the one-factor ANOVA test, was used. Durbin-Conover test, one of the Post-Hoc tests, was used to determine the source of the difference between groups. The Durbin-Conover test allows for Bonferroni correction in nonparametric tests (Conover, 1999). In the research findings, Bonferroni correction was applied to avoid making Type 1 mistakes. Descriptive analysis technique was used in the analysis of the qualitative data of the study. Due to the nature of the integrative mixed design, qualitative data have the quality to sample and support the quantitative data of the research. Therefore, the categories and codes of the qualitative data are the sub-dimensions and items of the DLMER.

A pilot study was conducted with five pre-service teachers in order to test the construct validity and reliability of the DLMER and to determine the possible deficiencies in advance. In the pilot study, digital learning material was prepared for pre-service teachers in line with the learning outcome determined. Thus, it has been tested whether the dimensions of the DLMER and its performance indicator are sufficient. Together with two faculty members and researchers who are experts in the fields of computer and mathematics education, the results of the pilot study were analyzed and the suitability of the DLMER was determined. The questions in the semi-structured interview form were determined at this stage. Qualitative and quantitative data support each other because the quantitative data of the study are sampled by qualitative data. This situation increased the reliability of the data.

Throughout the current study, ethical principles were adhered to. Informed consent form was presented to the participants before starting the study. Explanations about the nature of the study were included in the informed consent form. In addition, it was explained to the participants that the study will be carried out on a voluntary basis and that personal information will not be used outside the purpose of the study. The principles of scientific research and publication ethics were followed in the process of establishing the theoretical framework of the study, data collection, analysis and interpretation of data. References to other publications in the study were made in accordance with scientific rules and these were presented in the reference in accordance with the APA style.

\section{Results}

\section{Comparison of material evaluation skills}

Descriptive statistics are given in Table 1 below in order to summarize the results of the participants in terms of material evaluation sub-dimensions.

Table 1. Descriptive Statistics for Sub-Dimensions of Material Evaluation

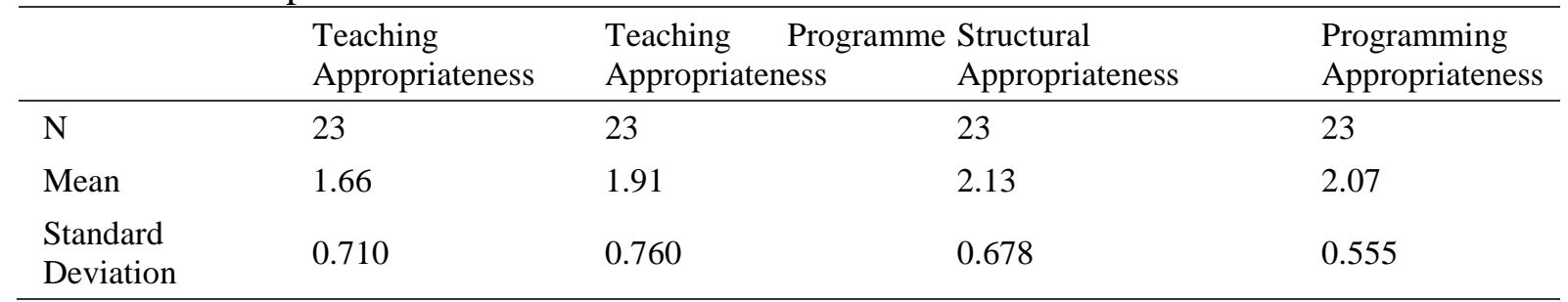


In Table 1, when the average score of pre-service teachers is examined in terms of digital learning material design, it is seen that Structural Appropriateness dimension has the highest average score and Teaching Appropriateness dimension has the lowest average. Friedman Test was applied to determine whether there is a significant difference in terms of digital learning material design sub-dimensions and results of the test are given in Table 2.

Table 2. Friedman Test Results

\begin{tabular}{lll}
\hline 2 & $\mathrm{~d}$ & 1 \\
\hline 1.2 & 1.010 \\
\hline
\end{tabular}

According to Friedman Test analysis results given in Table 2, there is a statistically significant difference between pre-service teachers' digital learning material design subdimension average scores $\left(\chi^{2}(3)=11.2, \mathrm{p}<0.05\right)$. The Durbin-Conover test from the post Hoc tests was used to determine which sub-dimensions differ in twos. In Table 3, the analysis results of the Durbin-Conover test are given.

Table 3. Pairwise Comparisons (Durbin-Conover)

\begin{tabular}{lll}
\hline & Value & $\mathrm{p}$ \\
\hline Teaching Appropriateness - Teaching Programme Appropriateness & 2.3431 & 0.022 \\
Teaching Appropriateness - Structural Appropriateness & 3.1241 & 0.003 \\
Teaching Appropriateness - Programming Appropriateness & 3.0531 & 0.003 \\
Teaching Programme Appropriateness - Structural Appropriateness & 0.7810 & 0.438 \\
Teaching Programme Appropriateness - Programming Appropriateness & 0.7100 & 0.480 \\
Structural Appropriateness - Programming Appropriateness & 0.0710 & 0.944 \\
\hline
\end{tabular}

Durbin-Conover test results were evaluated by making a Bonferroni correction. Therefore, the degree of significance was used as $0.05 / 6=0.008$. In Table 3 , there is a significant difference between teaching appropriateness and structural appropriateness $(3.124, \mathrm{p}<0.008)$ and between teaching appropriateness and programming appropriateness $(3.053, \mathrm{p}<0.008)$. When this finding is evaluated together with the average scores of the sub-dimensions in Table 1, it is seen that pre-service teachers are more successful in terms of structural appropriateness and programming appropriateness than teaching appropriateness in developing digital teaching materials.

\section{Examination of material evaluation skills}

In this section, materials designed by pre-service teachers are examined in terms of material evaluation skills. In accordance with the framework of the study, it was presented in the categories of teaching appropriateness, teaching programme appropriateness, structural appropriateness and programming appropriateness.

\section{Examination in the dimension of teaching appropriateness}

Teaching appropriateness refers to a material's ability to activate learning and to increase motivation, the adequacy of a material's content related to the subject being taught, and the extent to which that material has the information about the content. Figure 1 shows 
screenshots of a digital learning material that lacks teaching appropriateness in two different cases.

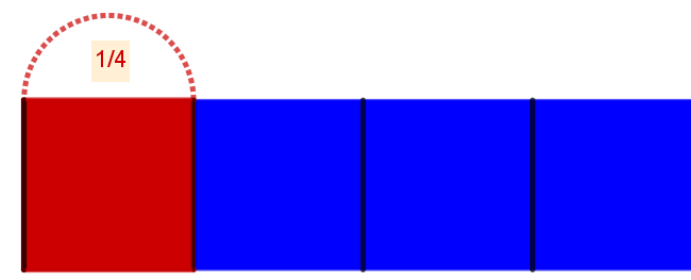

Case One
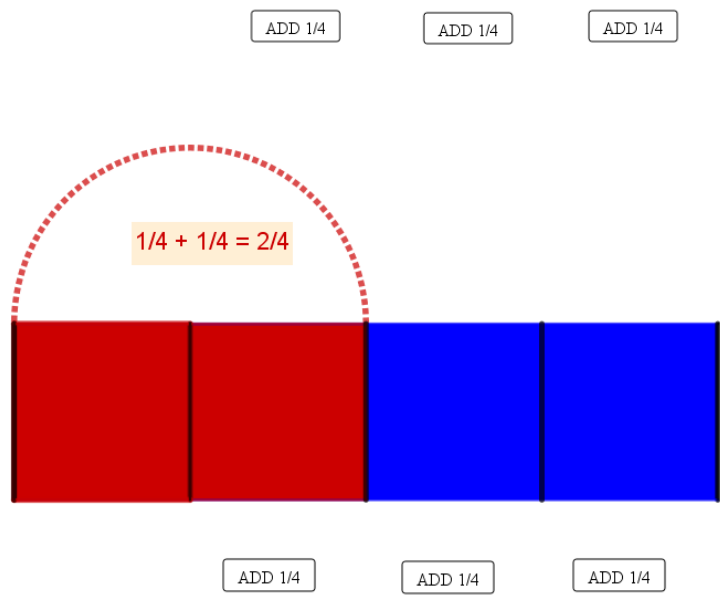

Case Two

Figure 1. Screenshots from Design of Pre-service Teacher A

In the design of pre-service teacher A given in Figure 1, adding equal parts to the fraction $1 / 4$ and obtaining 1 whole is shown with animations. In terms of teaching appropriateness, it can be said that digital instructional material contains some elements related to activating learning, such as buttons called "reset" and "add $1 / 4$ ". But the fact that the design applied only for a fraction $1 / 4$ caused the digital learning material of the pre-service teacher to be incomplete in terms of content and insufficient in terms of activating learning. In addition, there are no elements like buttons or notes that direct you to start which are related to motivation. Since the digital learning material designed by the pre-service teacher A does not contain any explanations, it is also insufficient to provide any summary or efficient information. Figure 2 shows screenshots of a digital learning material design by pre-service teacher $\mathrm{H}$ that lacks teaching appropriateness in two different cases.

$$
\frac{4}{8}+\frac{1}{5}=\frac{7}{10}
$$

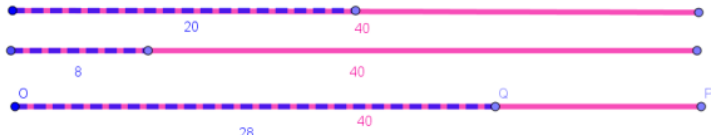




$$
\frac{8}{9}+\frac{1}{6}=\frac{19}{18}
$$

Now let's model the addition process above.

Case Two

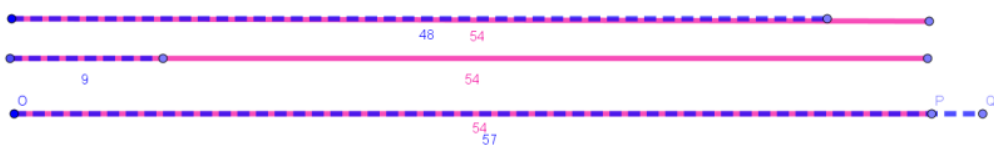

Figure 2. Screenshots from Design of Pre-service Teacher H

In the design of the pre-service teacher $\mathrm{H}$ given in Figure 2, two fractions are modeled separately, and the sum of these fractions is modeled at the bottom. In the material designed by the pre-service teacher $\mathrm{H}$, there is only a "New Question" button in terms of interaction. In this way, multiple models are randomly generated. But it is not possible for the students to determine the fractions they want. This has reduced the adequacy of the material in terms of activating learning. In addition, there are no motivational elements in the design. When the content of the material is examined, it is seen that during the addition of fractions whose denominators are not the same in the first case, the denominators are equalized by multiplication of the denominators, rather than finding the least common multiple of these two denominators. In addition, the lack of points showing the unit and equal parts in the created model is also an indicator of the lack of content. This deficiency made the model erroneous and incomprehensible when an improper fractional result was obtained, as in the second case. The lack of any information or explanation of the subject taught in the digital learning material shows that the material is inadequate for providing the necessary information. Therefore, it can be said that the digital learning material designed by the preservice teacher $\mathrm{H}$ does not meet the criteria for teaching appropriateness.

The following results were reached when examining the comments of pre-service teachers related to teaching appropriateness:

- A pre-service teacher's comment: "by pressing the 'New Fraction' button, various simple fractions appear to have been added" shows that he intended only to model simple fractions when designing. It shows that the lack of consideration of all fraction types has shortcomings in its design related to teaching appropriateness.

- Comment of pre-service teacher H: "the parts we are forced to: 1-) we did not want the sum of two fractions to be a composite fraction, we could not do it, 2-) modelling should not look the same when the numerators are the same, but the denominators are different, but it looks the same, we cannot correct it, and modelling also cannot show the result written in a simplified way" shows that he is aware of the lack of content adequacy.

\section{Examination in teaching programme appropriateness}

Teaching programme appropriateness refers to the fact that the material is suitable for different learning styles, contributes positively to student success, is flexible in terms of use, 
and the student can use the material alone. Figure 3 shows screenshots of a digital learning material that lacks teaching programme appropriateness in two different cases.

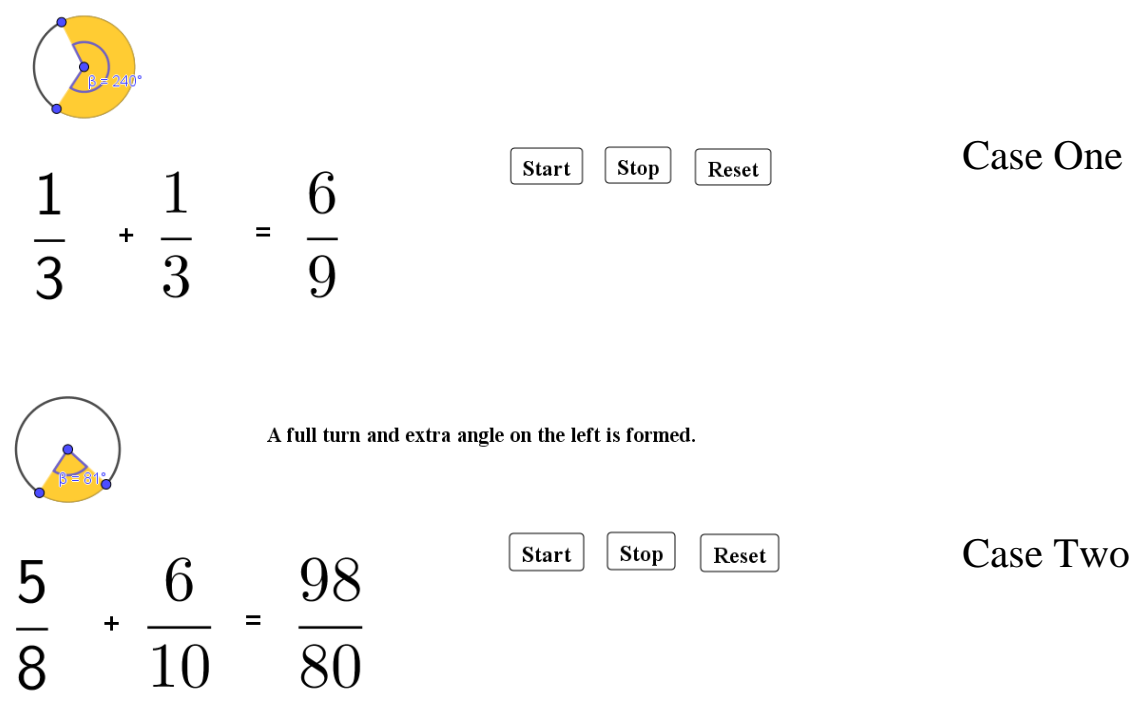

Figure 3. Screenshots from Design of Pre-service M

In the design of the pre-service teacher $M$ given in Figure 3, it is aimed to show the result of two random fractions with a circle model. With the "start" button, the fractions increase randomly, while the "stop" button stops the increase, and the "reset" button brings the fractions to the initial state (the two fractions are being set to $\frac{1}{3}$ ). The fact that the buttons in the design are intended only to pause randomness, that is, the user cannot determine fractions, and user interaction is limited to this, indicates that the design is not suitable for different learning styles. When the design is evaluated in terms of making a positive contribution to student success, only the part which is more than a whole is shown in the circular fraction model in the case where the result is an improper fraction (the second case). The whole part was shown with the phrase "a full turn and extra angle on the left is formed". Therefore, in the case of improper fractional results, the model does not work properly, and the design is insufficient in terms of making a positive contribution to student success in this aspect. This lack of model also impairs the flexibility of the design in terms of use. Another deficiency of the material is the lack of any orientation, summary information, and suchlike for the student to use the material alone. As a result, it can be said that the digital design of the pre-service teacher $\mathrm{M}$ has shortcomings in terms of teaching programme appropriateness. Figure 4 shows two screenshots of the design of the pre-service teacher P. 
New Operation

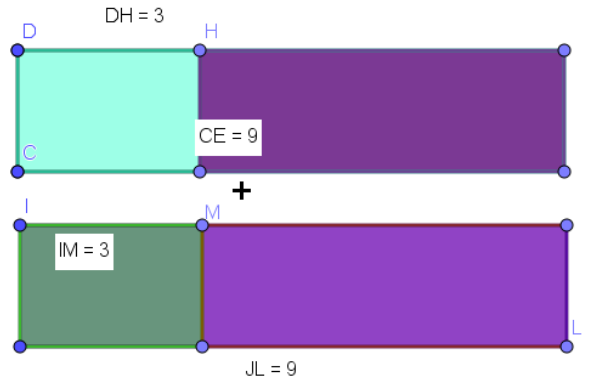

Case One

$$
\frac{3}{9}+\frac{3}{9}=\frac{3+3}{9}
$$

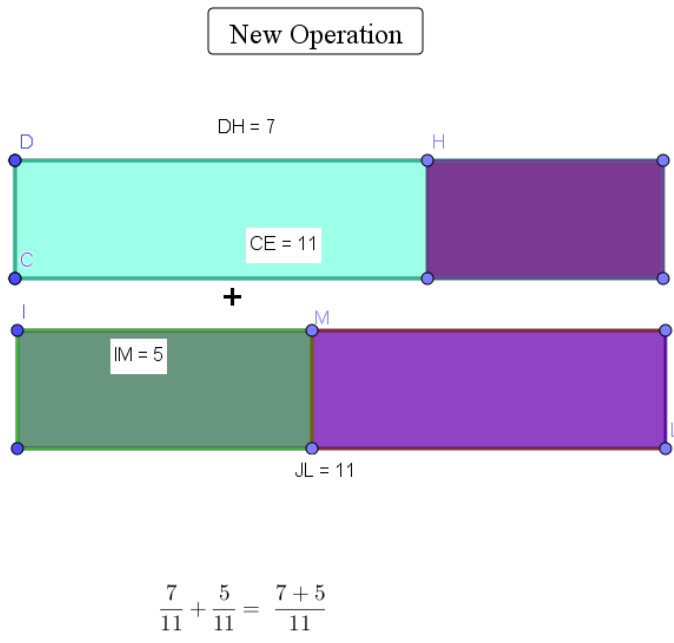

Case Two

Figure 4. Screenshots from Design of Pre-service Teacher $P$

In the design of the P pre-service teacher given in Figure 4, two simple fractions are modeled, and the addition of these two fractions is shown by writing under the model. When the "new operation" button is pressed, both fraction models are updated with the new simple fractions. As in the previous example, user interaction is quite limited since the design creates random values only with the "new operation" button. This has caused the design to be limited in its suitability for different learning styles. The competence of the design in teaching the target outcome is lacking due to the shortcomings in the model. Because the sum of two fractions is not modeled while the initial two fractions are modeled. Therefore, it will not be possible to understand how the addition of fractions process occurs through the model. In addition, since both fractions have the same denominator, the addition process in unlike fractions has been ignored in the design. Therefore, the model is not flexible in terms of its use. It can be said that the material is insufficient for the student to use it alone, as the model does not contain elements such as orientation, description. As a result, the digital design of the $\mathrm{P}$ pre-service teacher has shortcomings in terms of applicability to the curriculum.

The following conclusions were reached when examining the comments of pre-service teachers in the dimension of teaching programme appropriateness: 
- Comments of pre-service teacher M: "I was hesitant about what numerical expressions I shall write in the design of the material for the material to be useful" can be interpreted as having concerns about making a positive contribution to student success and the design's being suitable for different learning styles. However, the fact that the material design only works in certain situations shows that there are also shortcomings related to flexibility in terms of use.

- Comments of pre-service teacher P: "we created the sum of simple fractions randomly produced by pressing buttons, and also tried to create the sum of simple fractions formed by the numbers we entered ourselves" shows that they have shortcomings related to making a positive contribution to student success, since it does not fully cover the gain.

\section{Examination in the dimension of structural appropriateness.}

Structural appropriateness refers to the harmonious colors used in the material, the effective use of screen space, the simplicity of the design, and the legibility of the screen. Figure 5 shows screenshots of a digital learning material that lacks structural appropriateness in two different cases.

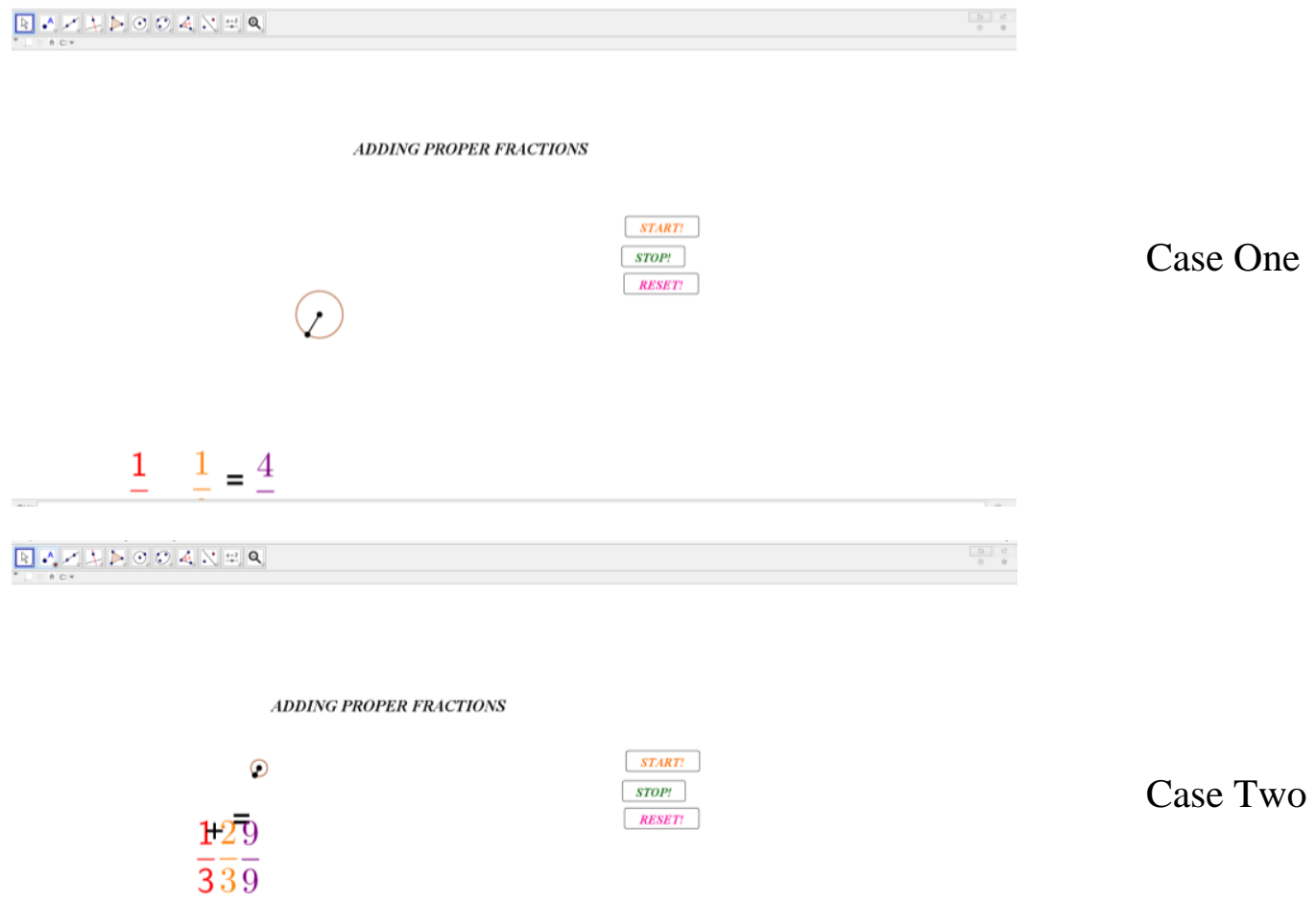

Figure 5. Screenshots from Design of Pre-service Teacher L

The material prepared by the pre-service teacher L given in Figure 5 aims to show the result of the sum as a model according to the fractions that change when the buttons are pressed. In the first case, a screenshot of the first version of the material opened with the GeoGebra application without zooming in or out is shown. In the second case, zooming out is resorted to with a view to showing the invisible objects. In both cases, there appear to be problems with the use of screen space, screen simplicity, and screen readability. In addition, the choice of 
font colors used in buttons also seems problematic in terms of color compatibility. In Figure 6 , digital learning material designed by candidate B teacher is shared.

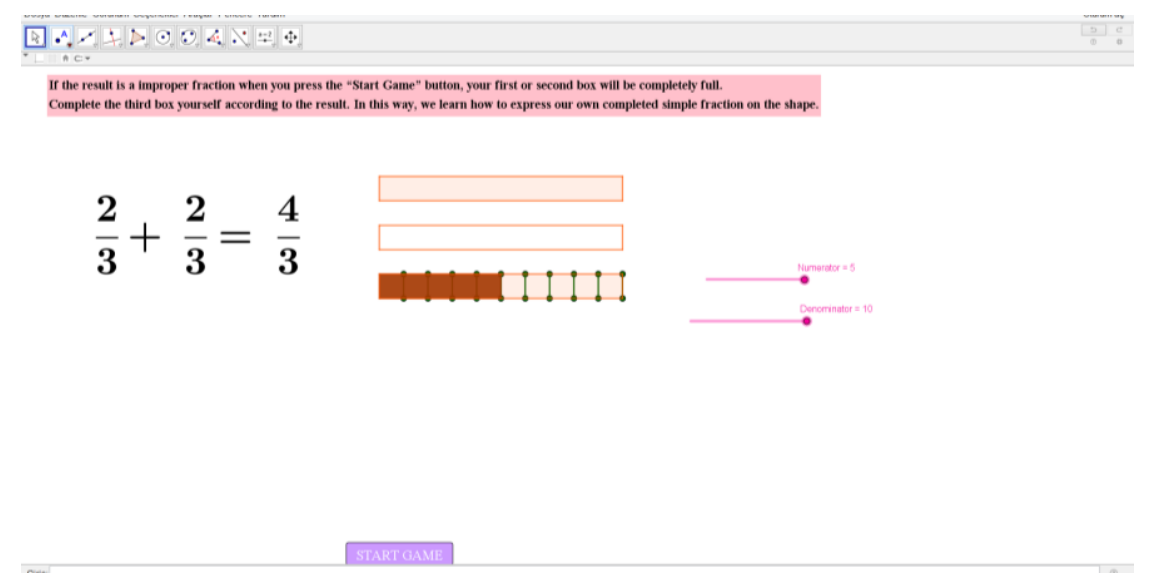

Figure 6. A Screenshot from the Design of the Pre-service Teacher B

The material prepared by pre-service teacher B given in Figure 6 is a game for the sum of two fractions. The description in the pink box and the "Start Game" button do not exactly fit on the screen. This makes the material incomplete in terms of the use of screen space and in terms of screen readability. The fact that the "numerator" and "denominator" sliders, which are the control mechanisms of the game, are on the edge and the colors are too bright stands out as a lack of simplicity of the design. In addition, the lack of a color tonality between buttons, sliders, description and the model indicates that the material does not contain color harmony.

The following results were reached when examining the comments of pre-service teachers in the structural appropriateness dimension:

- Comments of pre-service teacher L: "we colored the design we made because the group we addressed was secondary school students" indicates that the design takes into account structural appropriateness in terms of coloring (color selection) appropriate to the student level.

- "The reason we do this is to save time in the lesson and get a place in the student's visual memory. The most difficult part was to create shapes according to fractions and after collecting, to write and create an integer fraction shape". His interpretation shows that he aims to bring visuals to the forefront in his design.

Examination in the dimension of programming appropriateness.

Technical competence refers to the error-free operation of the material, to have instructions on its use, to have an appropriate level of interaction and to be suitable for use with all equipment. Figure 7 shows screenshots of a digital learning material that lacks programming appropriateness in two different cases. 


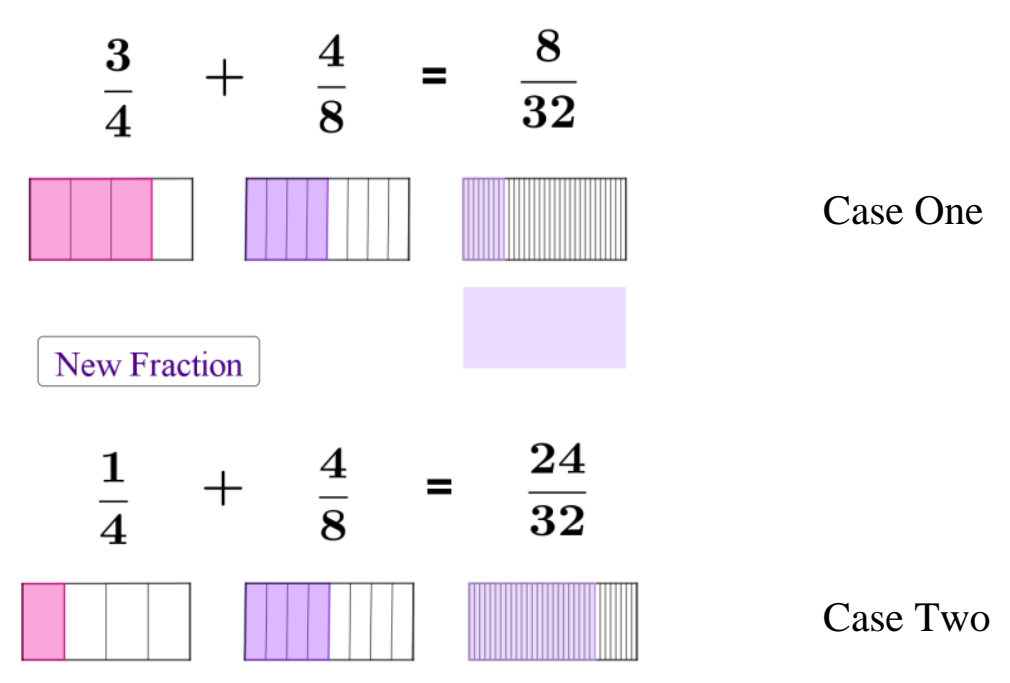

New Fraction

Figure 7. Screenshots from Design of Pre-service Teacher S

The material prepared by the pre-service teacher $\mathrm{S}$ given in Figure 7 shows the two fractions with unlike denominators and the sum of these fractions as a model. In the first case, the model shows the sum of fractions correctly, while the result of the addition shown in writing is incorrect. A directive on how to use the material is also not included. In addition, the level of interaction is limited by the "new fraction" button, which allows random fractions to occur. Figure 8 shows two screenshots of the design of the pre-service teacher S.

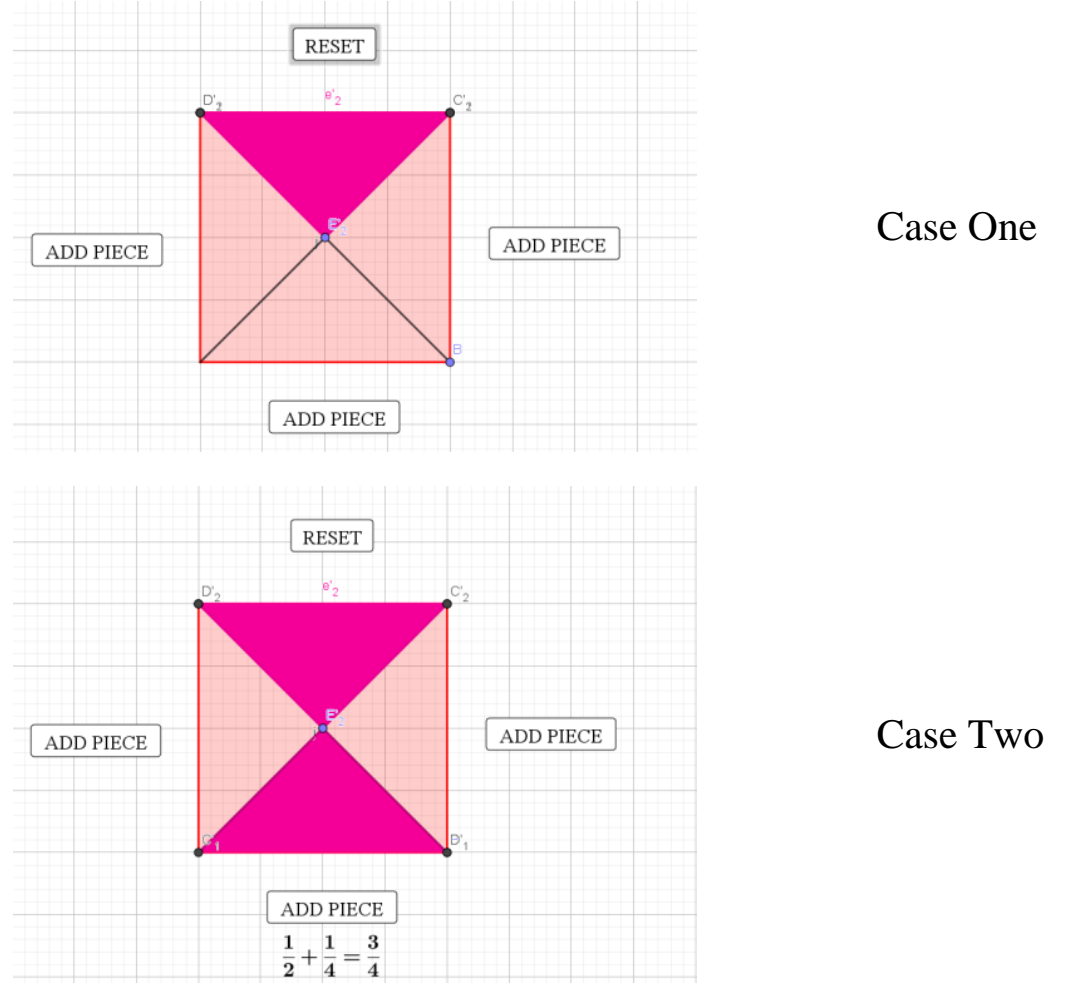

Figure 8. Screenshots from Design of Pre-service Teacher N 
In the design of the pre-service teacher $\mathrm{N}$ given in Figure 8, quarter magnitudes are added to the fraction model with the "add piece" button. The model works smoothly by pressing the "add piece" buttons on the left, then the bottom, and finally on the right. But when this sequence is not followed, erroneous situations arise. For example, in the second case, the button at the bottom is pressed in the picture given, in which the model shows a fraction of $1 / 2$, while the description shows the result as $3 / 4$. The presence of a separate button for the movement of each part has increased the level of interaction of the material. It appears that the material does not contain any instructions for use.

The following results were reached when examining the comments of pre-service teachers in the size of technical competence:

- Pre-service teacher S's interpretation of "In doing this, we had difficulty showing the numerator and denominator through the figure with the shape construction phase, using the array command and presenting the feedback to the student." shows that he has difficulty preparing a design that works technically error-free and presenting the appropriate level of interaction.

- Pre-service teacher N's comment that "the parts that we had difficulty with this assignment were creating animations and giving commands to buttons" again shows the difficulty of ensuring the appropriate level of interaction.

\section{Discussion, Conclusions and Recommendations}

When the DLMER scores of the pre-service teachers who participated in the study were examined, it was found that there were deficiencies in the digital learning material design skills of the pre-service teachers. When we examined these identified deficiencies, it was observed that pre-service teachers made modeling for a special situation (for example, designing materials for simple fractions only; designing materials for fractions whose denominators are equal). On the other hand, it was determined that pre-service teachers made incomplete / incorrect designs motivationally because they did not use a sentence or a remarkable object that visually encourages or initiates use. In addition to this result, it was observed that there were also technically and visually erroneous situations in the designs of pre-service teachers. Especially, it is stated that the readability of the prepared materials is low due to the mismatch of the texts and colors; it has been determined that the materials do not work in different situations (for example, if the result of the operation is an improper fraction) and the buttons and menus in the materials are not designed properly. In interviews with pre-service teachers, it was observed that they were aware of their shortcomings in terms of material design. However, it was determined that they had difficulty in overcoming this situation and could not reflect the models they planned to create into the software. This result coincides with the similar results in the study of Hırça and Şimşek (2013) and Tarraf (2017).

As a result of examining the digital designs of pre-service teachers, it was concluded that they were less successful in terms of teaching appropriateness than structural appropriateness and programming appropriateness. When this situation is evaluated in terms of Technological Pedagogical Content Knowledge [TPACK] (Kohler \& Mishra, 2005), it can be interpreted as pre-service teachers are more competent in terms of technological knowledge but they are weaker in terms of content knowledge. On the contrary, the results of the lack of technological knowledge of pre-service teachers in the studies (Hew \& Brush, 2007; Riasati, Allahyar \& Tan, 2012; Wilson, Ritzhaupt, \& Cheng, 2020) are not in line with the results of this study. In addition, this finding, which coincides with the ones in other studies, indicates 
that although pre-service teachers have sufficient computer skills, they have deficiencies in integrating the curriculum with technology (Lloyd, 2013; Karaca, 2015).

When the digital learning materials designed by the pre-service teachers were examined according to the sub-dimensions of the DLMER, deficiencies in each dimension were encountered in different ways. When the designed digital learning materials are examined in the context of the instructional suitability dimension of DLMER; it was concluded that the pre-service teachers had difficulty in preparing materials suitable for the content and they could not prepare materials for the students to actively participate. As in this study, it has been stated in other studies that pre-service teachers who are not well aware of teaching appropriateness will have difficulties in selecting appropriate materials as well as preparing suitable materials (Krulik \& Rudnick, 1995; Kutluca \& Birgın, 2007; Korkmaz, Usta, \& Güzeller, 2009; Erseyin \& Güler, 2018).

When the designed digital learning materials are examined in the context of the teaching programme appropriateness dimension of the DLMER; it was concluded that the pre-service teachers made designs that did not fully cover the specified subject and did not attach enough importance to educational explanations and directions. Deficiencies in coverage of the subject to be taught are thought to be caused by deficiencies in pre-service teachers' curriculum literacy levels. As a matter of fact, studies in the literature show that pre-service teachers have deficiencies regarding curriculum literacy (Bayam, 2014; Moon, 2014; Çetinkaya \& Tabak, 2019; Karamanoğlu, 2019). When the results are analyzed in the context of structural appropriateness dimension; it was concluded that the pre-service teachers could not adjust the areas and spaces of the GeoGebra software screen in accordance with the material and used colors that were incompatible with each other. The reason for the deficiencies in structural appropriateness was interpreted as the material design principles were not sufficiently taken into account by prospective teachers (Dă̆ \& Kırıkkaya, 2012; Neebe, 2017; Ünlü, 2017). In terms of programming appropriateness, it was concluded that pre-service teachers could not create the content that would provide the mathematical feature of the very material.

In the context of the research results, taking into account the updated curriculum program, the following suggestions can be made:

- It is recommended that the digital learning materials to be prepared in "ComputerAssisted Mathematics Teaching" and "Material Design in Mathematics Teaching" courses must include certain evaluation criteria.

- It is recommended to include digital learning material design studies in "ComputerAssisted Mathematics Teaching" and "Material Design in Mathematics Teaching" courses.

- Considering the shortcomings of pre-service teachers in the stages of digital learning material preparation, it is recommended to shape the content of the "ComputerAssisted Mathematics Teaching" and "Material Design in Mathematics Teaching" courses.

- In "Material Design in Mathematics Teaching" courses, it is recommended that not only concrete materials, but also digital learning materials should be included.

\section{References}

Akçay, H., Tüysüz, C., Feyzioğlu, B., \& Oğuz, B. (2008). Effect of computer aided and computer assisted chemistry instruction on students' attitudes and success. Mersin 
University Journal of the Faculty of Education, 4(2), 169-181. Retrieved from https://dergipark.org.tr/tr/pub/mersinefd/issue/17385/181690

Aktepe, V. (2011). The classroom teachers' views on computer use in their courses. Ahi Evran University Journal of Kırşehir Education Faculty, 12(3), 75-92. Retrieved from https://dergipark.org.tr/en/pub/kefad/issue/59494/855121

Baki, A., Aydın Yalçınkaya, H., Özpınar, İ., \& Çalık Uzun, S. (2009). Comparing views of primary school mathematics teachers and prospective mathematics teachers about instructional technologies. Turkish Journal of Computer and Mathematics Education, 1(1), 65-83. Retrieved from https://dergipark.org.tr/en/pub/turkbilmat/issue/ $21560 / 231419$

Bayam, S. B. (2014). Matematik eğitiminde matematik tarihi gerekliliğinin felsefi temelleri ve gerçekçi matematik eğitiminde matematik tarihinin önemi[Philosophical foundations of the necessity of the history of mathematics in mathematics education and the importance of mathematics history in realistic mathematics education.]. Dört Öge, (5), 233-244. Retrieved from https://dergipark.org.tr/en/pub/dortoge/issue/40202/478609

Bayturan, S. (2011). The effect of computer-assisted instruction on the achievement, attitude and computer self-efficacy of students in mathemetics education [Unpublished doctoral dissertation]. Dokuz Eylul University, Institute of Educational Sciences.

Biber, A. Ç., Tuna, A., \& Aktaş, O. (2013). Students' misconceptions of fractions and its effect on solving fractions problems. Trakya University Journal of Education, 3(2), 152-162. Retrieved from https://dergipark.org.tr/en/pub/trkefd/issue/21474/230175

Bryman, A. (2007). Barriers to integrating quantitative and qualitative research. Journal of Mixed Methods Research, 1(1), 8-22. https://doi.org/10.1177/2345678906290531

Buteau, C., Jarvis, D. H., \& Lavicza, Z. (2014). On the integration of computer algebra systems (CAS) by Canadian mathematicians: Results of a national survey. Canadian Journal of Science, Mathematics and Technology Education, 14(1), 35-57. https://doi.org/10.1080/14926156.2014.874614

Büyüköztürk, Ş. (2016). Sosyal bilimler için veri analizi el kitabı[Handbook of data analysis for social sciences]. Ankara: Pegem Akademi.

Çakır, R., \& Oktay, S. (2013). Teachers' use of technology as becoming information society. The Journal of The Industrial Arts Education Faculty of Gazi University, 30, 35-54. Retrieved from https://dergipark.org.tr/tr/pub/esef/issue/28790/308083

Çetinkaya, S., \& Tabak, S. (2019). Curriculum literacy efficiency of preservice teachers. Ondokuz Mayis University Journal of Education Faculty, 38(1), 296-309. Retrieved from https://dergipark.org.tr/en/pub/omuefd/issue/46119/535482

Conover, W. J. (1999). Practical nonparametric statistics (Third ed.). Wiley: USA.

Creswell, J. W., \& Creswell, J. D. (2017). Research design: Qualitative, quantitative, and mixed methods approaches. Sage Publications.

Dağ, F., \& Kirıkkaya, E. B. (2012). Preparation of web-based teaching materials for natural processes in 8th grade: different views on the material of professionals. Education Sciences, 7(1), 212-229. Retrieved from https://dergipark.org.tr/en/pub/nwsaedu/issue/ $19817 / 211992$

Demirel, Ö. (2011). Öğretim ilke ve yöntemleri: Ögretme sanatı[Teaching principles and methods: The art of teaching] (17th edition). Ankara: PegemA Yayınc1lik.

Demirel, Ö., \& Yağcı, E. (2017). Eğitim, öğretim teknolojisi ve iletişim[Education, instructional technology and communication]. In Demirel, Ö. \& Altun, E. (Eds.). Ögretim teknolojileri ve materyal tasarımı/Instructional technologies and material design] (9th edition) (pp. 2-26). Ankara: PegemA Yayıncılık. 
Erensayın, E., \& Güler, Ç. (2018). The adaptation of multimedia software evaluation form into Turkish culture. Van Yuzuncu Yil University Journal of Education, 15(1), 13321354. Retrieved from https://dergipark.org.tr/en/pub/yyuefd/issue/40566/495658

Galip, G., \& Öksüz, C. (2010). Teaching 5th grades polygon and quadrilateral subjects through dynamic geometry software. Kastamonu Education Journal, 24(3), 15511566. Retrieved from https://dergipark.org.tr/en/pub/kefdergi/issue/22607/241656

Greene, J. C. (2007). Mixed methods in social inquiry. San Francisco: Jossey-Bass.

Haser, Ç., \& Ubuz, B. (2003). Student's conception of fractions: a study of 5th grade students. Hacettepe University Journal of Education, 24, 64-69. Retrieved from http://www.efdergi.hacettepe.edu.tr/shw_artcl-909.html

Heafner, T. (2004). Using technology to motivate students to learn social studies. Contemporary Issue in Technology and Teacher Education, 4(1), 42-53. Retrieved from https://www.learntechlib.org/primary/p/21905/

Hew, K. F., \& Brush, T. (2007). Integrating technology into K-12 teaching and learning: Current knowledge gaps and recommendations for future research. Educational technology research and development, 55(3), 223-252. https://doi.org/10.1007/s11423-006-9022-5

Hohenwarter, M., \& Jones, K. (2007). Ways of linking geometry and algebra, the case of GeoGebra. Proceedings of the British Society for Research into Learning Mathematics, 27(3), 126-131. Retrieved from http://eprints.soton.ac.uk/id/ eprint $/ 50742$

Inan, F. A., \& Lowther, D. L. (2010). Laptops in the K-12 classrooms: Exploring factors impacting instructional use. Computers \& Education, 55(3), 937-944. https://doi.org/10.1016/j.compedu.2010.04.004

İşman, A. (2015). Öğretim teknolojileri ve materyal geliştirme[Instructional technologies and material development] (5th edition). Ankara: PegemA Yayınc1lık.

Kahramanoğlu, R. (2019). A study on teachers' levels of curriculum literacy. Journal of International Social Research, 12(65), 827-840. http://dx.doi.org/10.17719 /jisr.2019.3495

Karaca, F. (2015) Investigation of pre-service teachers' technological pedagogical content knowledge based on a variety of characteristics. International Journal of Higher Education, 4(4), 128-136. https://doi.org/10.5430/ijhe.v4n4p128

Karal, H., Fiş Erümit, S., \& Çimer, A. (2010). Designing and evaluation of the computer aided teaching material about reproduction of plants. Journal of Turkish Science Education, $\quad 7(2), \quad 158-174$.

Retrieved from http://www.tused.org/index.php/tused/article/view/516

Karamustafaoğlu, O. (2012). How computer-assisted teaching in physics can enhance student learning. Educational Research and Reviews, 7(13), 297-308. https://doi.org/10.5897/ERR11.272

Kelly, A. C. (2006). Using manipulatives in mathematical problem solving: a performancebased analysis. The Montana Mathematics Enthusiast, 3(2), 184- 193. Retrieved from https://scholarworks.umt.edu/tme/vol3/iss $2 / 6$

Kılıç, Ç., \& Özdaş, A. (2010). Fifth grade students used representations while solving problems which require comparison and ordering in fractions. Kastamonu Education Journal, 18(2), 513-530. Retrieved from https://dergipark.org.tr/en/pub/kefdergi/issue/49063/626009

Koehler, M.J., \& Mishra, P. (2005). What happens when teachers design educational technology? The development of technological pedagogical content knowledge. Journal of Educational Computing Research, 32(2),131-152. https://doi.org/10.2190/0EW7-01WB-BKHL-QDYV 
Kolburan Geçer, A. (2010). Experience of technical teacher candidates towards teaching tecnologies and material development course. Van Yuzuncu Yil University Journal of Education, 7(2), 1-25. Retrieved from https://dergipark.org.tr/en/pub/yyuefd/issue/ $13710 / 165987$

Korkmaz, Ö., Usta, E., \& Güzeller, C. O. (2009). The competencies of pre-service teachers on the selection of educational software and their related perspectives. Ahi Evran University Journal of Kırşehir Education Faculty, 10(3), 135-142. Retrieved from https://dergipark.org.tr/en/pub/kefad/issue/59508/855701

Koşar, E., \& Çiğdem, H. (2003). Eğitim ortamı tasarımı, araç-gereç ve materyal özellikleri. Öğretim teknolojileri ve materyal geliştirme[Educational environment design, equipment and material properties. Instructional technologies and material development]. Ankara:PegemA Yayınc1lık.

Krulik, S., \& Rudnick, J. A. (1995). The new sourcebook for teaching reasoning and problem solving in elementary school. A longwood professional book. Allyn \& Bacon. Retrieved from https://eric.ed.gov/?id=ED387339

Kutluca, T., \& Birgin, O. (2007). Evaluation of prospective mathematics teachers views about. Gazi University Journal of Gazi Educational Faculty, (27)2, 81-97. Retrieved from http://www.gefad.gazi.edu.tr/tr/pub/issue/6750/90764

Kutluca, T., \& Zengin, Y. (2011). Evaluation of views of students about using GeoGebra in teaching of mathematics. Dicle University Journal of Ziya Gökalp Education Faculty, 17, 160-172. Retrieved from https://dergipark.org.tr/en/pub/zgefd/issue/47948/606660

Lloyd, M. (2013). Something's coming, something good: Identifying TPACK competence in pre-service teachers' analyses of learning objects. Australian Educational Computing, 28(1). Retrieved from https://journal.acce.edu.au/index.php/AEC/ article/view/12

Mills, G. E., \& Gay, L. R. (2016) Education research: Competencies for analysis and applications. London, England: Pearson Education.

Mishra, P., \& Koehler, M. J. (2006). Technological pedagogical content knowledge: A framework for teacher knowledge. Teachers College Record, 108(6), 1017-1054. Retrieved from https://www.learntechlib.org/p/99246/

MoNE, (2018). Matematik dersi öğretim programı. (İlkokul ve Ortaokul 3,4,5,6,7 ve 8. Siniflar) [Mathematics lesson curriculum. (Primary and Secondary School 3,4,5,6,7 and 8th Grades)]Retrieved from http://mufredat.meb.gov.tr/Dosyalar/ 201813017165445-MATEMAT\%C4\%B0K\%20\%C3\%96\%C4\%9ERET\%C4\%B0M $\% 20$ PROGRAMI\%202018v.pdf

Moon, B. (2014). The literacy skills of secondary teaching undergraduates: Results of diagnostic testing and a discussion of findings. Australian Journal of Teacher Education (Online), 39(12), 111-130. Retrieved from https://search.informit.org/doi/10.3316/ informit.852598682001661

Moskal, Barbara M. (2000). Scoring rubrics: what, when and how?. Practical Assessment, Research \& Evaluation, 7(3), 1-5. https://doi.org/10.7275/a5vq-7q66.

Neebe, D. C. (2017). Differentiating literacy instruction for digital learners: The effect of multimedia think-aloud worked examples on adolescent analytical reading comprehension. [Unpublished doctoral dissertation]. University of San Francisco.

Olkun, S., \& Toluk-Uçar, Z. (2014). Illköğretimde etkinlik temelli matematik ögretimi[Activity-based mathematics teaching in primary education] (6th edition). Ankara: Eğiten Kitap.

Onal, N., \& Göloğlu Demir, C. (2013). The effect of computer assisted geometry instruction on seventh grade school students' achievement. Turkish Journal of Education, 2(1), 19-28. https://doi.org/10.19128/turje.181051 
Orhun, N. (2007). A cognitive gap between formal arithmetic and visual representation in fractional operations. Inonu University Journal of the Faculty of Education, 8(14), 99111. Retrieved from https://dergipark.org.tr/en/pub/inuefd/issue/8709/108731

Ornstein, A. C., \& Lasley, T. J. (2000). Strategies for effective teaching (3rd ed.). Boston, USA: McGraw Hill Higher Education.

Özkurt, M.F. (2017). The relation between the class teachers senses of self efficacy with teaching technologies and talents of materiel designing [Unpublished master's thesis]. Necmettin Erbakan University.

Phillips, M. (2013). Investigating in-service teachers' workplace TPACK development. Australian Educational Computing, 28(2). Retrieved from https://journal.acce.edu.au/index.php/AEC/article/view/23

Plano Clark, V. L., \& Creswell, J. W. (2011). Designing and conducting mixed methods research. Sage Publications.

Preiner, J. (2008). Introducing dynamic mathematics software to mathematics teachers: the case of GeoGebra. [Unpublished doctoral dissertation]. Faculty of Natural Sciences, University of Salzburg.

Riasati, M. J., Allahyar, N., \& Tan, K. E. (2012). Technology in language education: Benefits and barriers. Journal of education and practice, 3(5), 25-30. Retrieved from https://www.iiste.org/Journals/index.php/JEP/article/view/1495

Şahin, T. Y., \& Yıldırım, S. (2001). Öğretim teknolojileri ve materyal geliştirme [Instructional technologies and material development]. Ankara: Anı Yayınc1lık.

Şendurur, P., \& Arslan, S. (2017). Investigation of changes in factors affecting the technology integration in education. Mehmet Akif Ersoy University Journal of Education Faculty, (43), 25-50. Retrieved from https://dergipark.org.tr/en/pub/maeuefd/issue/ $31552 / 345824$

Sharp, J., \& Adams, B. (2002). Children's constructions of knowledge for fraction division after solving realistic problems. The Journal of Educational Research, 95(6), 333-347. https://doi.org/10.1080/00220670209596608

Sipahioğlu, S. (2019). Investigation of primary science teachers' attitudes toward use of technology in education according to various variables [Unpublished master's thesis]. Atatürk University, Erzurum.

Somyürek, S. (2014). Gaining the attention of generation $\mathrm{z}$ in learning process: augmented reality. Educational Technology Theory and Practice, 4(1), 63-80. https://doi.org/10.17943/etku.88319

Soydan, C. (2018). Investigation of digital learning material development processes of field teachers in guidance of information technologies teacher [Unpublished master's thesis]. Ondokuz Mayis University, Graduate School of Educational Sciences.

Stevenson, M., Bower, M., Falloon, G., Forbes, A., \& Hatzigianni, M. (2019). By design: Professional learning ecologies to develop primary school teachers' makerspaces pedagogical capabilities. British Journal of Educational Technology, 50(3), 12601274. https://doi.org/10.1111/bjet.12743

Takıcak, M. (2016). Salih zeki's view to philosophy of mathematics: nâmütenâhî. Dört Öge, (9), 191-200. Retrieved from https://dergipark.org.tr/tr/pub/dortoge/issue/ $40210 / 478779$

Tarraf, H. (2017). Solving polynomial inequalities with GeoGebra [Unpublished doctoral dissertation]. Lebanese American University.

Teo, T. (2009). Modelling technology acceptance in education: A study of pre-service teachers. Computers \& Education, 52(2), 302-312. https://doi.org/10.1016/j.compedu. 2008.08.006 
Tezci, E., \& Perkmen, S. (2013). Oluşturmacı perspektiften teknolojinin öğrenme-öğretme sürecine entegrasyonu[Integration of technology into the learning-teaching process from a constructivist perspective].In K. Çağıltay, \& Y. Göktaş (Eds.). Öğretim teknolojilerinin temelleri: Teoriler, araştırmalar, eğilimler [Instructional technology foundations: Theories, research, trends](pp. 185-211). Ankara: PegemA Yayınc1l1k.

The Jamovi Project, (2020). Jamovi (Version 1.2) [Computer Software]. Retrieved from https://www.jamovi.org

Turel, Y. K., \& Sanal, S. O. (2018). The effects of an ARCS based e-book on student's achievement, motivation and anxiety. Computers \& Education, 127, 130-140. https://doi.org/10.1016/j.compedu.2018.08.006

Ünlü, M . (2017). Pre-service mathematics teachers' views about using instructional materials in mathematics lessons. Journal of Theory and Practice in Education, 13(1), 10-34. Retrieved from https://dergipark.org.tr/en/pub/eku/issue/27642/291326

Uyangör, S.M., \& Ece, D.K. (2010). The attitudes of the prospective pathematics teachers towards instructional technologies and material development course. TOJET: The Turkish Online Journal of Educational Technology, 9(1), 213-220. Retrieved from https://eric.ed.gov/?id=EJ875784

Uz, İ. (2018). An investigation of secondary school 5th grade students' self-efficacy toward fractions [Unpublished master's thesis]. Dokuz Eylul University, Institute of Educational Sciences.

Van De Walle, J. A. (2013). Elementary and middle school mathematics: Teaching devolopmentally. (7th edition). United States of America: Pearson Education.

Wilson, M. L., Ritzhaupt, A. D., \& Cheng, L. (2020). The impact of teacher education courses for technology integration on pre-service teacher knowledge: A meta-analysis study. Computers \& Education, 156(103941), 1-16. https://doi.org/10.1016/j.compedu. 2020.103941

Yazıc1, N. (2013). A comparative investigating of the effect of rubrics used based on SOLO Taxonomy on the measurement of success [Unpublished master's thesis]. Kahramanmaraş Sütçü İmam University, Institute of Social Sciences. 